\title{
Article
}

\section{COVID-19 Pandemic Effect on Energy Consumption in State Universities: Michoacan, Mexico Case Study}

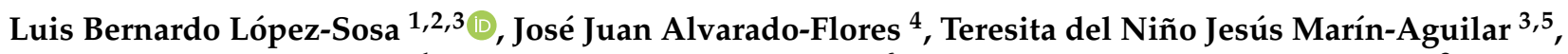 \\ Juan Carlos Corral-Huacuz ${ }^{1}$, Arturo Aguilera-Mandujano ${ }^{6}$, Gerardo Manuel Rodríguez-Torres ${ }^{3}$, \\ Mario Morales-Máximo ${ }^{1,4} \mathbb{C}^{-}$, María del Carmen Rodríguez-Magallón ${ }^{1,7}$, Jorge Víctor Alcaraz-Vera ${ }^{8}\left(\mathbb{C}_{\text {, }}\right.$ \\ María Liliana Ávalos-Rodríguez ${ }^{9}$ @ , José Guadalupe Rutiaga-Quiñones ${ }^{4}$, Nancy Eloísa Rodríguez-Olalde ${ }^{4}$, \\ Magaly del Carmen Flores-Armenta ${ }^{3}$ and Carlos A. García ${ }^{2, *}$
}

1 Programa Académico de Posgrados, Universidad Intercultural Indígena de Michoacán, Carretera Pátzcuaro-Huecorio Km. 3, Pátzcuaro 61614, Michoacán, Mexico; lbernardo.lopez@uiim.edu.mx (L.B.L.-S.); jccorralh@gmail.com (J.C.C.-H.); mmoralesmaximo@gmail.com (M.M.-M.); maria.rodriguez@uiim.edu.mx (M.d.C.R.-M.)

2 Escuela Nacional de Estudios Superiores Unidad Morelia, Universidad Nacional Autónoma de México, Antigua Carretera a Pátzcuaro No. 8701, Col. Ex Hacienda de San José de la Huerta,

check for updates

Citation: López-Sosa, L.B.; Alvarado-Flores, J.J.; del Niño Jesús Marín-Aguilar, T.;

Corral-Huacuz, J.C.;

Aguilera-Mandujano, A.;

Rodríguez-Torres, G.M.;

Morales-Máximo, M.;

del Carmen Rodríguez-Magallón, M.; Alcaraz-Vera, J.V.; Ávalos-Rodríguez, M.L.; et al. COVID-19 Pandemic Effect on Energy Consumption in State Universities: Michoacan, Mexico Case Study. Energies 2021, 14, 7642. https://doi.org/10.3390/ en14227642

Academic Editor: Antonio Morán

Received: 1 October 2021

Accepted: 8 November 2021

Published: 15 November 2021

Publisher's Note: MDPI stays neutral with regard to jurisdictional claims in published maps and institutional affiliations.

Copyright: (c) 2021 by the authors. Licensee MDPI, Basel, Switzerland. This article is an open access article distributed under the terms and conditions of the Creative Commons Attribution (CC BY) license (https:// creativecommons.org/licenses/by/ $4.0 /)$. Morelia 58190, Michoacán, Mexico

3 Universidad Tecnológica de la Construcción, Nicolás Ballesteros 1200, Ciudad Industrial 4a Etapa, Morelia 58200, Michoacán, Mexico; tmarinaguilar@gmail.com (T.d.N.J.M.-A.); gmrodriguez@utec.mx (G.M.R.-T.); magaly_flores_a@hotmail.com (M.d.C.F.-A.)

4 Facultad de Ingeniería en Tecnología de la Madera, Universidad Michoacana de San Nicolás de Hidalgo, Edif. D. Cd. Universitaria, Santiago Tapia No. 403, Centro, Morelia 58000, Michoacán, Mexico; jjalvarado@umich.mx (J.J.A.-F.); rutiaga@umich.mx (J.G.R.-Q.); nrodriguez@umich.mx (N.E.R.-O.)

5 Universidad Tecnológica de Morelia, Av. Vicepresidente Pino Suarez 750, Ciudad Industrial, Morelia 58200, Michoacán, Mexico

6 Instituto de Investigación en Metalurgia y Materiales, Universidad Michoacana de San Nicolás de Hidalgo, Avenida Francisco, J. Mújica S/N Ciudad Universitaria, Morelia 58030, Michoacán, Mexico; aragma7@hotmail.com

7 Doctorado en Desarrollo Educativo con Énfasis en Formación de Profesores, Universidad Pedagógica Nacional 162, 20 de noviembre, Zamora de Hidalgo 59660, Michoacán, Mexico

8 Instituto de Investigaciones Económicas y Empresariales, Universidad Michoacana de San Nicolás de Hidalgo, Cd. Universitaria, Santiago Tapia No. 403, Centro, Morelia 58000, Michoacán, Mexico; talcarazv@hotmail.com

9 Centro de Investigaciones en Geografía Ambiental, Universidad Nacional Autónoma de México, Antigua Carretera a Pátzcuaro No. 8701, Col. Ex Hacienda de San José, Morelia 58190, Michoacán, Mexico; lrodriguez@ciga.unam.mx

* Correspondence: cgarcia@enesmorelia.unam.mx

Abstract: The COVID-19 pandemic has generated multiple impacts. In particular, in the educational sector, the virtual class modality generated changes in the patterns of energy consumption at the institutional level; the identification of this consumption will allow us to reflect on new energy saving and efficient use strategies. In this research, we present a case study of the effects of the COVID-19 pandemic on electricity consumption in 13 state universities in Michoacán, Mexico. Electric energy consumption has been evaluated before and during the presence of the COVID-19 between 2019 and 2020. The comparative analysis estimated the reduction in energy consumption and its economic and environmental impact. The results show a considerable decrease in electricity consumption, generating an average saving of $76.24 \mathrm{MWh} / \mathrm{month}$, which translates into an annual emission reduction from 2019 to 2020 of approximately $497 \mathrm{TnCO}_{2 \mathrm{e}}$, and in economic terms of $\$ 8,882.25$ USD each month. In general, it was identified that consumption patterns in the use of machinery and computer equipment for administrative activities were drastically reduced. If education continues in virtual or hybrid modes, energy consumption schemes will continue to decline and institutions could move towards resilient, affordable, and sustainable models of energy production and consumption.

Keywords: COVID-19; energy consumption; universities; impact environment; sustainability 


\section{Introduction}

At the end of 2019, the world experienced a new health crisis caused by the SARS-CoV-2 virus that quickly spread throughout the most remote corners of each country, state and localities [1,2]. During the first months of 2020, a global state of emergency was formally decreed, because the infection epidemic reached the pandemic phase that even increased and was more severe in 2021. The effects of this pandemic are unquantifiable, diversified and increasingly severe. All sectors of the population have been, are and will continue to be affected [3]. Productive and economic activities still have daily losses [4], and the final global economic impact of this pandemic is still unknown. The health sector faces a challenge that permeates the safety and well-being status of patients, doctors and nurses. On the other hand, it is also estimated that the educational system was not the same as it was before 2020; progress in this sector continues to be dynamic and the academic community is increasingly resilient [5].

In Mexico, the SARS-CoV-2 virus arrived between January and February $2020[6,7]$. The first case of COVID-19 was detected in Mexico on 27 February 2020 [8]; and in a large part of the national territory, the strategies for confinement and closure of ordinary activities began in March of the same year [9]. As in the rest of the world, economic activities in Mexico have suffered various effects since the first months of the pandemic [9].

The education sector was also affected-technological advances for the development of teaching activities came quite quickly. In a few months, the academic society migrated from an interactive and practical face-to-face system, to a mostly digital environment in online, distance and virtual modalities [10-12]. Virtuality became a periodic routine, and the blackboard and notebooks were replaced by components of computational nature [13,14]. The students had to immediately adapt to audiovisual sessions, sometimes asynchronous, and to be linked daily to a digital screen to attend lessons, tasks and activities complementary to the learning dynamics planned by the national educational sector. This digital scheme could only be possible for a fraction of Mexican society, only a percentage of those institutions located in urban areas, and institutions of upper and upper middle level, as well as for private institutions that are not funded by the state [15]. This increases the digital divide that accelerates educational inequality and has placed Mexico in 87th place worldwide in the use of information and communication technologies [16].

The rest of the Mexican student population with difficult access to the digital modality have maintained their teaching activities with total uncertainty, and have limited themselves to being in a teaching model of task submission and printed material to work from home and, in the best cases, to have frequent face-to-face sessions once a week. In Mexico, as in many developing countries [17], the reality of virtual education during the pandemic had two contexts: (a) those who adapted and maintained a resilient learning status and (b) those who were in precarious conditions, educational backwardness and each day tried to adapt to the systematization of education, whose progress achieved up to now, was voraciously consumed by the pandemic, leading to further lagging of the rural educational system [18-20]; the latter is the representation of the majority of Mexicans. Both contexts proposed to cover all educational levels, from the basic level called "Primaria" to the higher level, "Universitario" [21].

Although there are points in common at the different levels of the national educational system, the truth is that the one that represents the greatest changes in the lifestyle of young Mexicans is the University level [22,23], because students must move to areas distant from their home to the cities where the universities are located, which translates into various energy consumption patterns. In addition, they must pay variable fees for their education, as well as for rental, food and mobility services. This educational level promotes a local and regional economy scheme where the universities are located, due to the concentration of all student enrollment, which has generated a total economic dependence in many cities. The SARS-CoV-2 virus pandemic permeated these local economies and caused serious effects on the inhabitants where the universities are located, on the students who work to obtain income and pay their university expenses, and the institutions themselves 
due to changes in the patterns of functionality and economic sustainability. A particular change generated during the closure of these institutions was related to the consumption of electrical energy [24-26], which has been constant in all universities in the world, and European universities had reductions from $10 \%$ up to $40 \%$ [25]. It is estimated that in the first quarter of 2020, there was a saving of $3.8 \%$ in global energy demand compared to in the same quarter of 2019, as a consequence of the reduction in global economic activity and mobility [27-29], including the impact of the closure of higher education institutions.

It should be noted that university campuses use energy differently compared to residential buildings, and their consumption pattern is more complicated since it depends on many factors such as the physical characteristics of the facilities, the occupancy rate, heating, ventilation and air cooling according to the climate where the property is located, interior and exterior lighting, the number of computers, laboratory materials, charging sockets, and class periods throughout the year [25,30].

Energy consumption during the COVID-19 lockdown has been studied and quantified in various parts of the world. In general, the decrease in energy consumption during the COVID-19 pandemic has been reported in educational centers. A study carried out by Samuel et al. in 2021 in South African primary and secondary schools, with and without accommodation service, reports a decrease in energy use of $30 \%$ to $40 \%$ equivalent to 2-20 kWh per student per month [31]. Additionally, in some higher education institutions, the decrease in consumption has made it possible to estimate the reduction of the carbon footprint due to the decrease in mobility, the decrease in the generation of waste and the low energy consumption after the closure of the university buildings, which decreased by more than 10\% in some places in America, Europe and Asia [32,33], as well as the decrease in the use of air conditioning systems as in the United Kingdom for example at the University of Bournemouth [26], whose carbon footprint was reduced by approximately $30 \%$. On the other hand, in particular cases, such as the University of Almeria in Spain, energy consumption was reduced by 1.3 million $\mathrm{kWh}$ in 2020, with the largest decrease in library buildings and the smallest decrease in research buildings [25]. The reduction of electrical energy has also recently been studied in extracurricular spaces, for example, a research was carried out in university dormitories in the southern United States of America [34], which showed savings from confinement by COVID-19 of $40 \%$ in total electricity demand. Likewise, in a particular way, the reduction in electrical energy consumption could be identified in the buildings and laboratories of some universities in Europe, with significant levels of decrease, as has been reported in some studies [25,35]. This translates into reduced environmental impact [36-38] and energy costs.

In this context, it is interesting to carry out a comparative analysis between the environmental impacts caused by the activities of the universities before the COVID-19 pandemic and the activities that are being carried out remotely today, which has been addressed by Lopes et al. in institutions of Higher Education in Brazil [39], and that has allowed the use of environmental impact methodologies such as Life Cycle Analysis, to carry out more sophisticated studies. In addition, Clemson University has conducted a study of the reduction in energy consumption and the low estimated impacts in reducing its carbon footprint, in which case the decrease was approximately 30\% [40].

Additionally, electric lighting is quite significant in educational institutions. A study of schools in the United States showed that consumption by this activity represented between $20 \%$ and $30 \%$ in office buildings and consumed, on average, around $14 \%$ of energy in schools [25]. The consumption of electrical energy in these cases is even more important, considering the health emergency scenario and the changes in consumption patterns, on the one hand, because a diagnosis before, during and after the pandemic will allow the identification of a possible medium term energy efficiency and energy management programs; and on the other hand, because it will contribute to knowing the environmental impact of this pandemic; for example, globally, a decrease in greenhouse gas (GHG) emissions close to $8.8 \%$ was observed, only in the first half of 2020 [41]. Therefore, 
it can be seen that the environmental impact product of the health strategies was also representative [42].

Diagnostic studies of electrical energy consumption during the COVID-19 pandemic have made it possible to propose energy efficiency scenarios that promote energy saving and emission reduction [43]. It is important to know the current context to propose possible solutions with perspectives for energy sustainability. It is also important to mention that the studies that quantify the impact of the COVID-19 pandemic on energy consumption in educational centers are few, recent and increasingly necessary as they provide important information for planning the return to activities through comprehensive models that consider both the relevance of human contact [44] and its environmental impact [45-47].

In Mexico, there have been no systematic studies on electricity consumption in higher education institutions during the COVID-19 pandemic, which could contribute to establishing new energy efficiency and energy management programs after this health emergency. Therefore, in the first place, it is important to know the diagnosis of electricity consumption in universities by type of institution and in various socioeconomic regions of the country during this period, which will allow us to envision new energy scenarios for this educational sector. In addition, currently (November 2021) in the state of Michoacán, the state development plan is being formulated and multisectoral working groups are being generated; this plan should consider aspects related to energy management for the next 6 years. At the same time, there is a political dialogue for a new energy reform at the national level. Therefore, this type of research may contribute to incorporating the educational energy consumption sector into new government plans and programs with an impact on the national educational sector at the higher level.

This research performs a comparative analysis in the patterns of electricity consumption of 13 state universities located in Michoacán, Mexico. Studying energy consumption during the final months of 2019 and the months of the beginning and first peak of maximum infections of the SARS-CoV-2 virus in 2020, when the pandemic caused the closure of universities and classes, were maintained in a virtual modality. Three dimensions of the impacts of the closure of state universities are analyzed: (a) electricity consumption; (b) impacts on $\mathrm{CO}_{2 \mathrm{e}}$ emissions; and (c) the institutional economic impact. Therefore, the monthly variations in electrical energy have been estimated, as well as those variations in terms of energy costs, energy consumption per student capita and the reduction of equivalent $\mathrm{CO}_{2}$ emissions due to the reduction of electricity consumption. In a complementary way, collateral effects are discussed, formulating a scenario of impacts generated by the reduction of student mobility during this pandemic. The objective of this research is to diagnose energy consumption patterns during the COVID-19 pandemic, as well as the environmental and economic effects that make it possible to determine possible routes for restructuring the university energy system, and to establish the basis for the construction of new scenarios on the management and efficient use of electricity during and after the pandemic, encouraging the construction of alternative proposals for self-sufficiency through sustainable electricity supply strategies, also promoting reflection regarding energy consumption linked to the new normal and distance education schemes that, in the coming years, will be abundantly reproducible in most universities [48]. It is also expected to encourage the establishment of realities of satisfaction of electrical energy needs economically and with low environmental impact. In addition, this research contributes to knowing the dimension of the reduction of electrical energy consumption in the higher education sector and will allow the proposal of immediate scenarios for the construction of public policies and energy and technological transition programs in the studied state universities, considering the current changes in the national and state policy in energy matters that are being carried out this year.

\section{Materials and Methods}

The present work is a case study carried out in the state of Michoacán, in western Mexico. In this research, the total electrical energy consumption data from 13 public universities that are distributed throughout the State of Michoacán were analyzed (Figure 1). The data 
were collected from 2019 to 2020, to identify the variations in consumption associated with the change in patterns of teaching and academic-administrative activities in each of these universities. Electricity consumption for each university was obtained with data referred institutionally by the Federal Electricity Commission (CFE). With these data, a consumption baseline was determined and then an energy saving estimate was made before and during the presence of the pandemic.

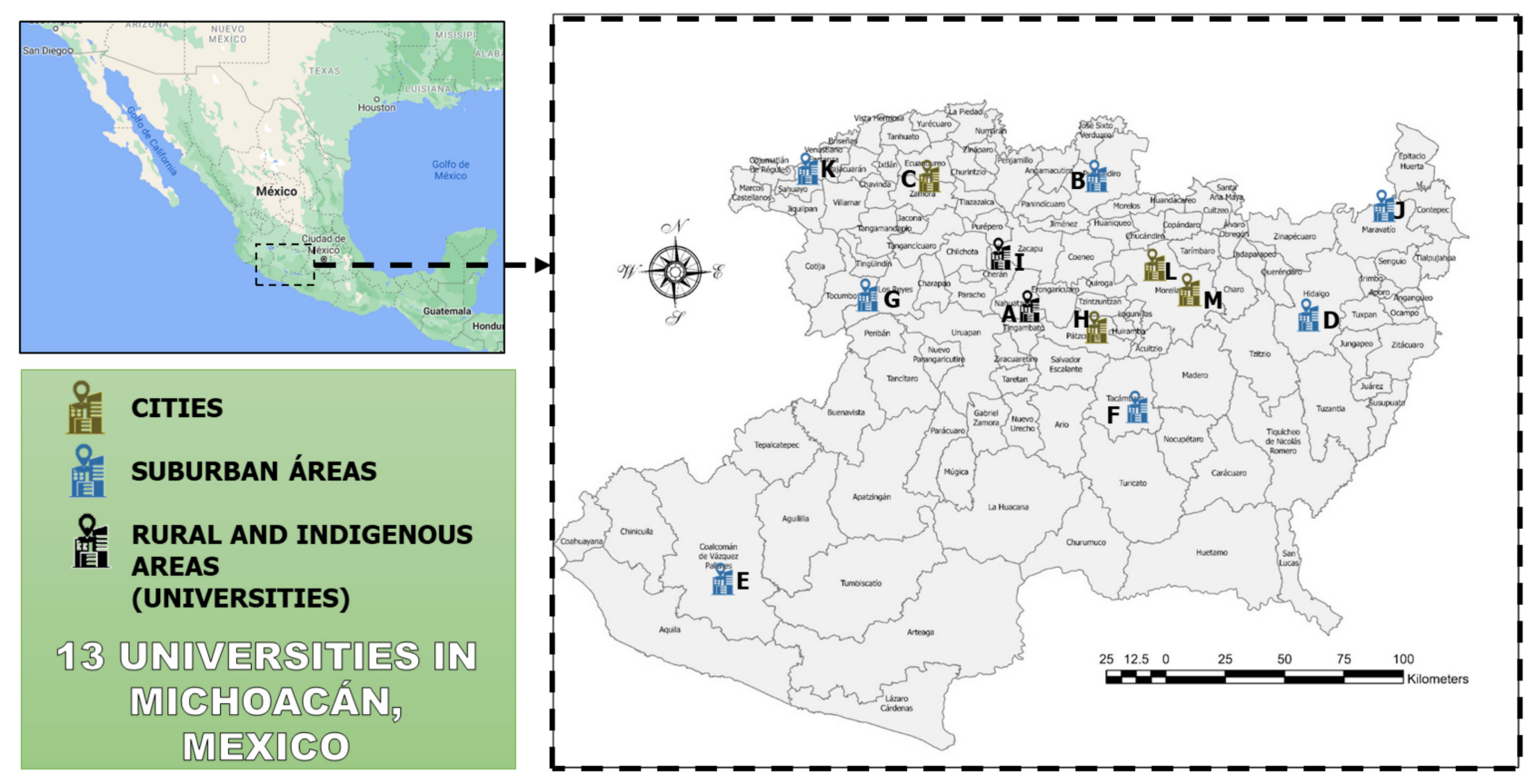

Figure 1. Location and distribution of the case study.

The universities of study are located in regions of small cities, rural and indigenous regions and suburban areas in small municipalities. These universities maintain organizational schemes of single venues with majority enrollments, and host between 431 and 3155 students per university, according to the datamexico.org platform of the Ministry of Economy of the Government of Mexico. These institutions belong to a decentralized scheme, which provides higher and postgraduate education to low-income young people, whose university academic offer is aimed at addressing local problems with undergraduate, engineering and postgraduate degrees that can promote local development, so it is common for them to have infrastructure such as machine and tool workshops, computer laboratories and physicochemical laboratories, as well as some specialized laboratories for the performance of the activities of each offered academic program. Other activities associated with the consumption of electricity are lighting and, in a few cases, space heating.

In Mexico, the health contingency plan due to COVID-19 began in March 2020, with the partial closure of educational institutions, businesses and government offices. Although for the month of April 2020 the Mexican national educational system was already generating virtual distance teaching strategies, in that same month there was the vacation period that each year takes place between the months of March or April (Holy Week) for two continuous weeks and is mandatory in all public schools. On the other hand, to contrast the electricity consumption data with the contingency stages linked to the increase in COVID19 infections, data from the Mexican Health Secretariat and the Environmental Geography Information Center of the National Autonomous University of Mexico (CIGA-UNAM in Mexico) were used.

To carry out the economic and environmental analysis related to electricity consumption, data from the Energy Regulatory Commission (CRE) were used, considering an emission factor of $0.55 \mathrm{kgCO}_{2 \mathrm{e}}$ for each $\mathrm{kWh}$ of electricity consumption for the year 2020, these data will allow us to know the reduction of $\mathrm{CO}_{2}$ emissions [49]. The electricity costs 
for each $\mathrm{kWh}$ were estimated according to the average consumption rate, obtained from the consumption reports of each university, which are generated by the CFE, an institution in charge of providing the electricity supply nationwide. The identified electricity consumption patterns and the possible strategies for the use and self-consumption of energy after the pandemic are also discussed. Considering the trend of institutional economic savings on a monthly basis, a strategy for the implementation of solar lights is proposed for all the studied universities.

For confidentiality reasons, according to the Education Secretary in the State of Michoacán and the letter of authorization and use of data for this research SEE/SEMSyS/DES/ $129 / 202$, and practical use of data, the names of the universities will be omitted, only considering those names from the comparative analysis in the urban and indigenous sectors. The marginal notes of the 13 universities will have a nomenclature from the letters " $\mathrm{A}$ " to " $\mathrm{M}$ ", and only the initials of these institutions have been incorporated to identify them (Figure 1).

Additionally, with the database of the studied educational institutions, collateral effects of the pandemic linked to virtual teaching activities were also analyzed, generating a scenario of economic-environmental impact based on the decrease in mobility of student enrollment by university, considering an average mobility radius of $10 \mathrm{~km}$ in local public transport, in vehicles with automotive yields of $9.5 \mathrm{~km}$ per liter of consumption of gasoline, and mobility costs of 1 USD/day. Specifically, two universities are also compared, one in the urban sector and the other in the indigenous sector, in order to compare the various contexts and the impact of the pandemic in different socio-territorial spaces.

\section{Results}

With the total closure of Universities and virtual classes in April 2020, as well as the Easter holidays, the variation peaks in electricity consumption could be seen until May. From October 2019 to October 2020, a pattern in electrical energy consumption was identified for the studied universities. In this period, the monthly average electricity consumption data were identified; in the case of 2020, those months after May were taken into account, which are the months that showed decreasing trends, when all the institutions were already fully attending to the measures of the health emergency. Figure 2a shows the mentioned average consumption, while Figure $2 \mathrm{~b}$ shows the percentage of savings in energy consumption.

It can be seen that nine of the 13 studied universities maintained savings in electricity consumption of between $30 \%$ and $45 \%$ during the pandemic, while the rest have irregular savings. J University is the one that achieved the highest amount of savings because it is a university with smaller student enrollment and academic and administrative staff than the rest of the universities, it is recently created and is in the incipient phase of infrastructure. On the other hand, Universities K and L do not have significant savings, but it should be noted that University $\mathrm{L}$ is a virtual university, so its consumption has not been reduced due to its operating scheme that has not changed drastically, unlike the rest of the universities. " $\mathrm{K}$ " University has vast infrastructure that requires a high energy supply, and it is likely that much of its team was left working at a minimum, even so, the magnitude of infrastructure it has limits its decrease in energy. On the other hand, J University maintains the highest energy savings, probably because it is a recently created institution that did not maintain all consumption patterns like the rest of the universities, or perhaps, due to the low enrollment, the lighting system is limited. It is likely that there is little dependence on the spatial location and socioeconomic conditions where the universities are located, since the saving pattern has been maintained for most of the universities in the urban, suburban and rural and indigenous sectors. The monthly consumption patterns of a year, 2019-2020, which in sum represent a total average saving of $76.24 \mathrm{MWH} /$ month, can be seen in Table 1.

The savings trend that has been identified not only translates into a decrease in consumed electrical energy, it is also linked to a reduction in emissions in an institutional 
way. Figure 3a shows a comparative analysis of the generation of emissions associated with average electricity consumption for the months of 2019 and 2020; as expected, the amount of emissions generated by a university is directly proportional to electricity consumption. These emissions in general represented, for the year 2019, approximately 1212 tons of $\mathrm{CO}_{2 \mathrm{e}}$, and for 2020 approximately 712 tons of $\mathrm{CO}_{2 \mathrm{e}}$, which represents a reduction of about 500 tons per year in only 13 universities (Figure $3 b$ ), on average a mitigation 1.3 tons of $\mathrm{CO}_{2 \mathrm{e}}$ daily.

The mitigation of $\mathrm{CO}_{2 \mathrm{e}}$ emissions in universities, as in the rest of the world, as a result of the pandemic, is also significant [50] and it has been common in all the universities of the world [38]. In contrast, the reduction of $\mathrm{CO}_{2}$ emissions as a result of the reduction of energy consumption in universities $[38,46]$ has represented a mitigation strategy resulting from the pandemic, which has contributed to the reduction of the carbon footprint in the entire world's education sector [36].

Figure $3 \mathrm{~b}$ also shows the percentage contribution of institutional emissions for the total tons of $\mathrm{CO}_{2 \mathrm{e}}$ generated between 2019 and 2020. From these data, it stands out that institutions such as the virtual university have not had significant variations because its operation was not affected. Furthermore, analogous to energy consumption, there is no differentiation between the reduction in the percentage of emissions generated between universities in the urban, suburban or rural and indigenous sectors.
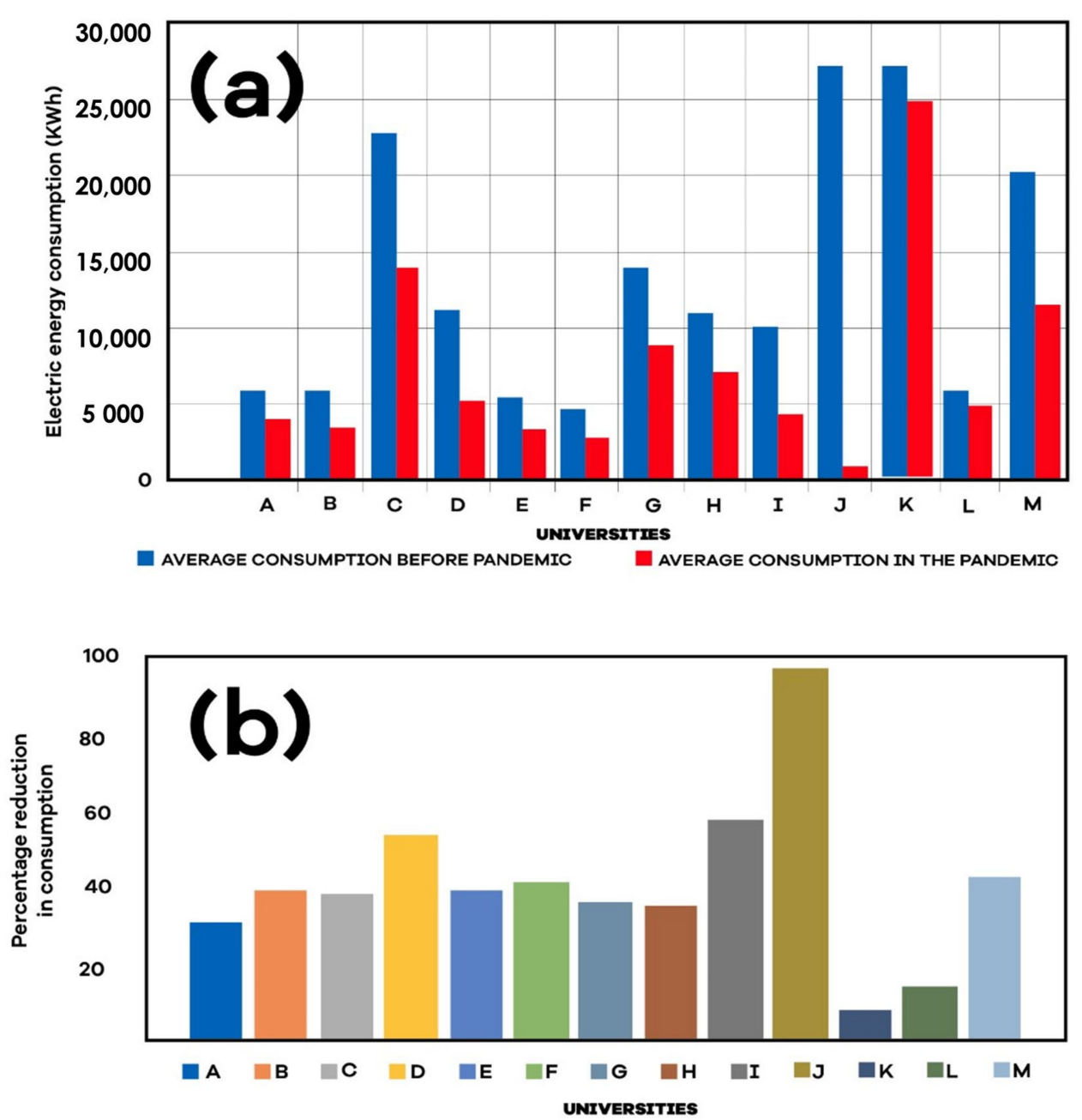

Figure 2. (a) Comparative analysis in the average monthly consumption of electrical energy 2019-2020 (b) Percentage of savings in electrical energy consumption in average months of 2019-2020. 
Table 1. Distribution of electricity consumption by university from October 2019 to October 2020 (MWh).

\begin{tabular}{|c|c|c|c|c|c|c|c|c|c|c|c|c|c|}
\hline Month & A & B & $\mathrm{C}$ & D & E & F & G & $\mathbf{H}$ & I & $\mathbf{J}$ & $\mathbf{K}$ & L & $\mathbf{M}$ \\
\hline October 2019 & 7.74 & 5.68 & 29.93 & 15.20 & 7.60 & 4.72 & 16.24 & 12.08 & 11.44 & 2.00 & 5.66 & 1.27 & 4.50 \\
\hline November 2019 & 7.36 & 6.64 & 25.64 & 15.19 & 6.40 & 5.04 & 16.48 & 12.80 & 2.08 & 0.46 & 32.38 & 6.99 & 24.86 \\
\hline December 2019 & 6.16 & 6.64 & 27.48 & 9.91 & 6.64 & 5.52 & 17.28 & 11.20 & 12.81 & 1.86 & 29.24 & 6.20 & 21.11 \\
\hline January 2020 & 5.84 & 3.84 & 22.33 & 9.84 & 4.48 & 5.12 & 9.04 & 9.52 & 10.45 & 1.60 & 28.40 & 6.50 & 21.59 \\
\hline February 2020 & 5.92 & 5.04 & 21.82 & 12.69 & 3.12 & 3.44 & 10.96 & 9.36 & 9.04 & 1.92 & 30.01 & 6.17 & 23.49 \\
\hline March 2020 & 3.92 & 6.16 & 26.94 & 10.22 & 4.96 & 4.24 & 15.44 & 11.44 & 12.16 & 2.40 & 30.81 & 6.25 & 19.26 \\
\hline April 2020 & 3.76 & 3.84 & 22.22 & 0.70 & 5.20 & 4.48 & 10.32 & 8.40 & 8.83 & 1.36 & 3.41 & 0.69 & 1.70 \\
\hline May 2020 & 3.76 & 3.20 & 1.97 & 4.54 & 2.80 & 2.72 & 6.80 & 7.12 & 0.62 & 0.30 & 22.63 & 4.47 & 10.54 \\
\hline June 2020 & 4.08 & 3.12 & 12.61 & 5.12 & 2.96 & 2.40 & 8.00 & 7.20 & 3.95 & 0.51 & 27.41 & 5.40 & 12.08 \\
\hline July 2020 & 3.92 & 2.24 & 14.64 & 5.12 & 3.04 & 2.24 & 7.84 & 6.40 & 4.30 & 0.53 & 29.54 & 5.24 & 11.35 \\
\hline August 2020 & 4.08 & 2.72 & 15.80 & 5.53 & 2.48 & 2.32 & 7.76 & 7.44 & 3.99 & 0.93 & 26.95 & 5.30 & 12.62 \\
\hline September 2020 & 4.00 & 2.64 & 15.61 & 5.98 & 3.20 & 2.32 & 7.44 & 7.12 & 4.01 & 1.00 & 30.06 & 5.95 & 12.92 \\
\hline October 2020 & 4.00 & 3.04 & 15.36 & 4.62 & 3.68 & 2.56 & 7.76 & 7.04 & 4.34 & 1.10 & 28.05 & 6.36 & 12.24 \\
\hline
\end{tabular}
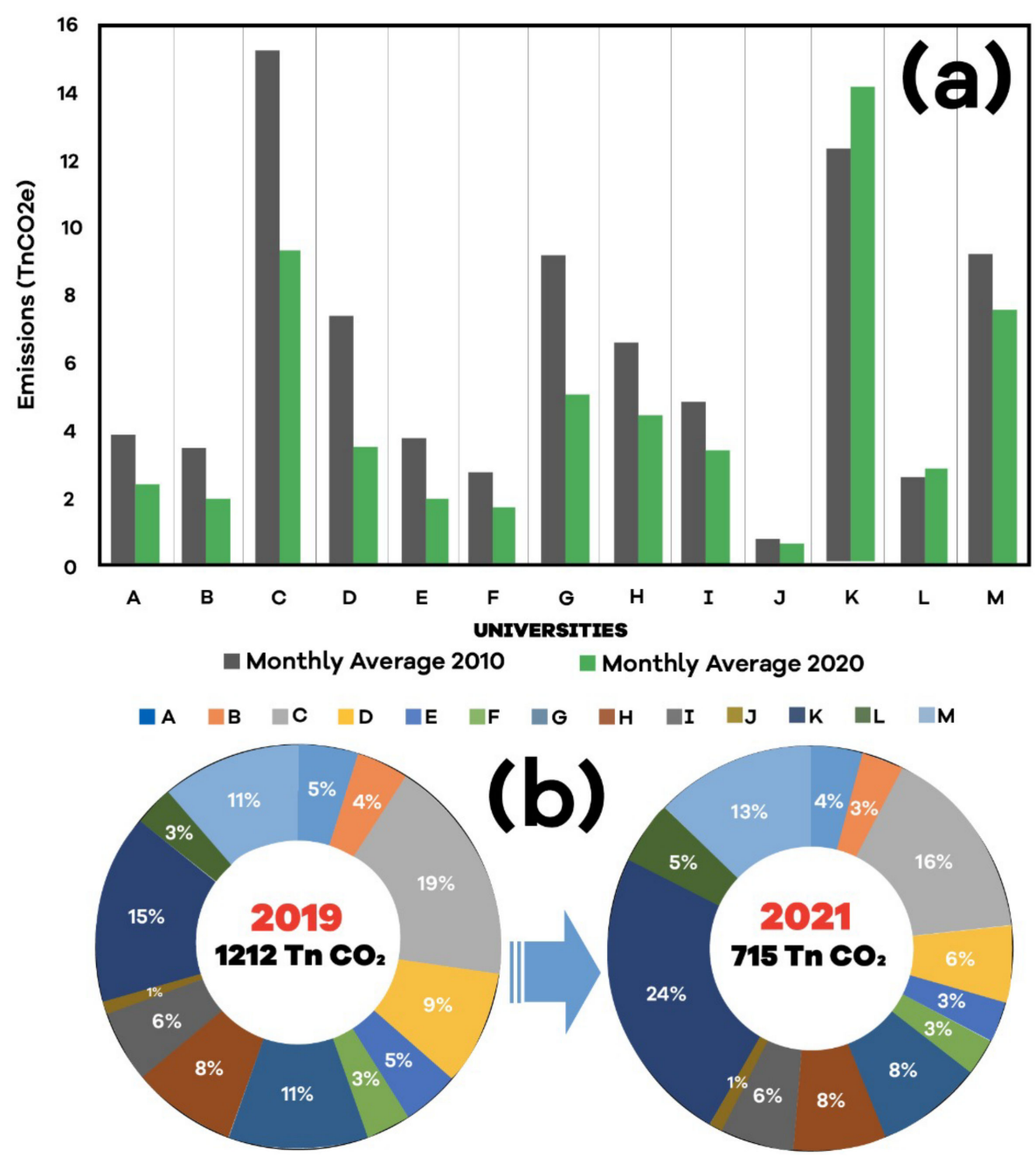

Figure 3. (a) Comparative analysis of monthly emissions per university for 2019 and 2020 (b) Analysis of annual emissions in the 13 study universities.

On the other hand, infections in 2020 in Mexico linked to SARS-CoV-2 increased from March to July, and it was in this last month when they reached the first maximum peak since the beginning of confinement. For the first half of July, the country reached the highest number of infections, and days later the decline in infections of this nature would begin. For the month of May, a substantial decrease in the consumption of electrical energy could be observed, a fact that coincides with the confinement throughout the country and when 
the universities closed their daily teaching and research activities. It should be noted that, in the month of March, the confinement began in the state of Michoacán, and Figure 4 shows the scenario of the evaluation of electrical energy consumption linked to the closure of universities and the increase in infections. In Figure $4 a$, the first maximum peak of infections is observed, which is linked to the closure of universities and economic and productive activities in the state of Michoacán.
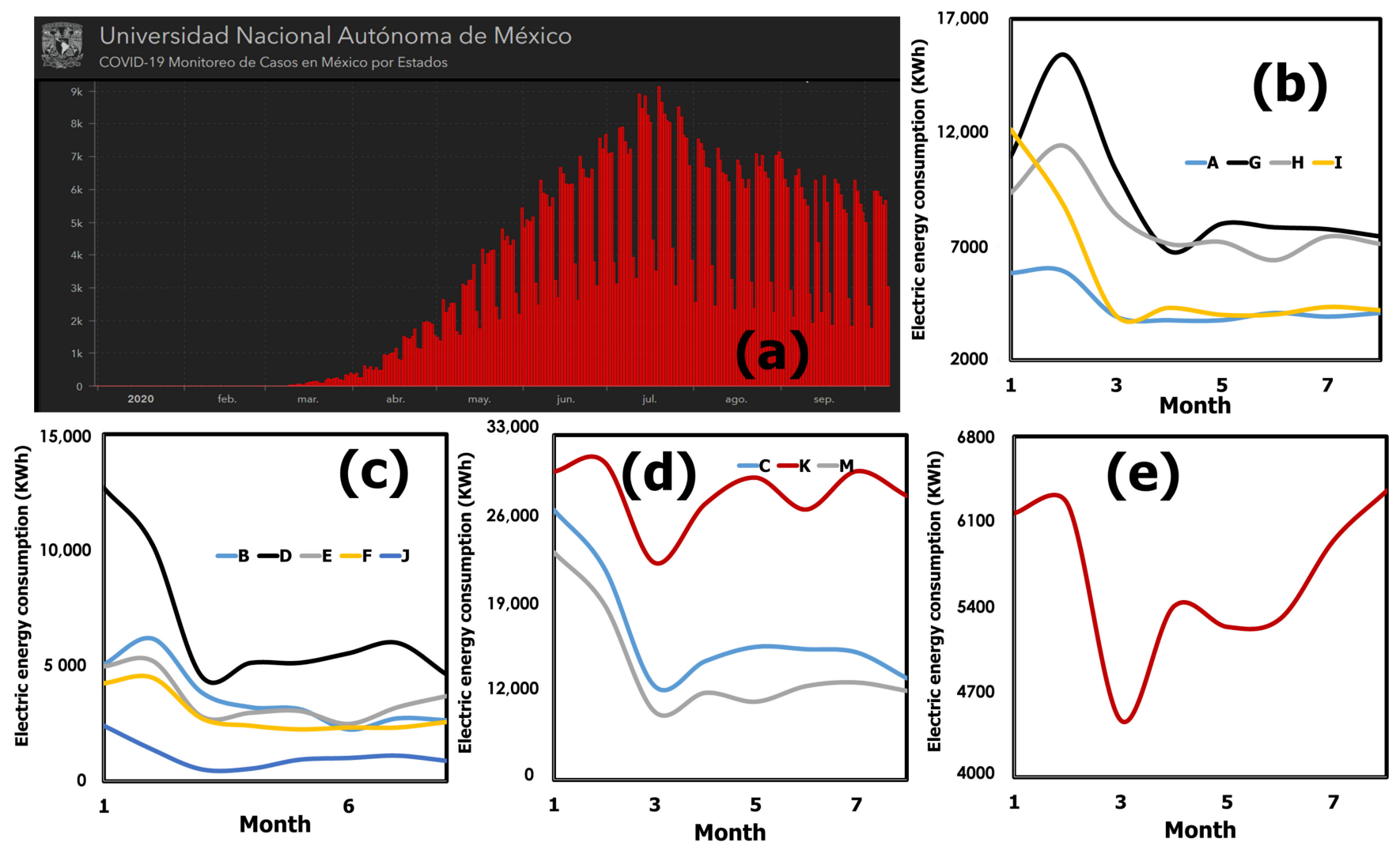

Figure 4. (a) Distribution of contagions until the first peak of 2020. Variation in energy consumption in the first months of confinement in Mexico (March = 1): (b) Universities in rural and indigenous areas (c) Universities in suburban and peri-urban areas (d) Universities in urban areas (e) Virtual University.

In particular, Figure $4 \mathrm{~b}$ shows the comparison in energy consumption for the universities that serve the population of rural and indigenous areas and are located in this type of region. As can be seen, there is a similar pattern of behavior in all the curves, differentiated only by the magnitude of consumption. As of July, energy consumption showed constant behavior in each university in these categories. Thus, for the universities that serve the population of suburban and peri-urban areas (Figure 4c), the behavior is analogous to the previous case, differentiated in the magnitude of energy consumption, something similar occurs with those universities that offer their higher education services to the population of urban areas (Figure 4d). On the other hand, a special case is the variations in electricity consumption that the Virtual University had, which drastically decreased its consumption in the months of April and May, but had an increase until it recovered its ordinary monthly average consumption in the month of September, although all its activities were virtual before and during the pandemic; this behavior is due to the suspension of face-to-face activities that allow the university to function, that is, the administrative and teaching staff were absent from the university due to the total closure of face-to-face activities during the months of lower consumption in 2020. In this sense, unlike the rest of the universities, the virtual university maintains its base consumption during the pandemic months after September 2020, while the rest stabilize a reduction in the consumption of electrical energy. 
These universities serve thousands of young people from the state of Michoacán and neighboring states. Figure 5a shows the distribution of student enrollment in the studied universities. This distribution does not present a specific pattern; the urban, periurban, suburban and rural sectors do not determine the total number of students per university, each region where they are located shows diverse contexts allowing enrollment to be diverse.
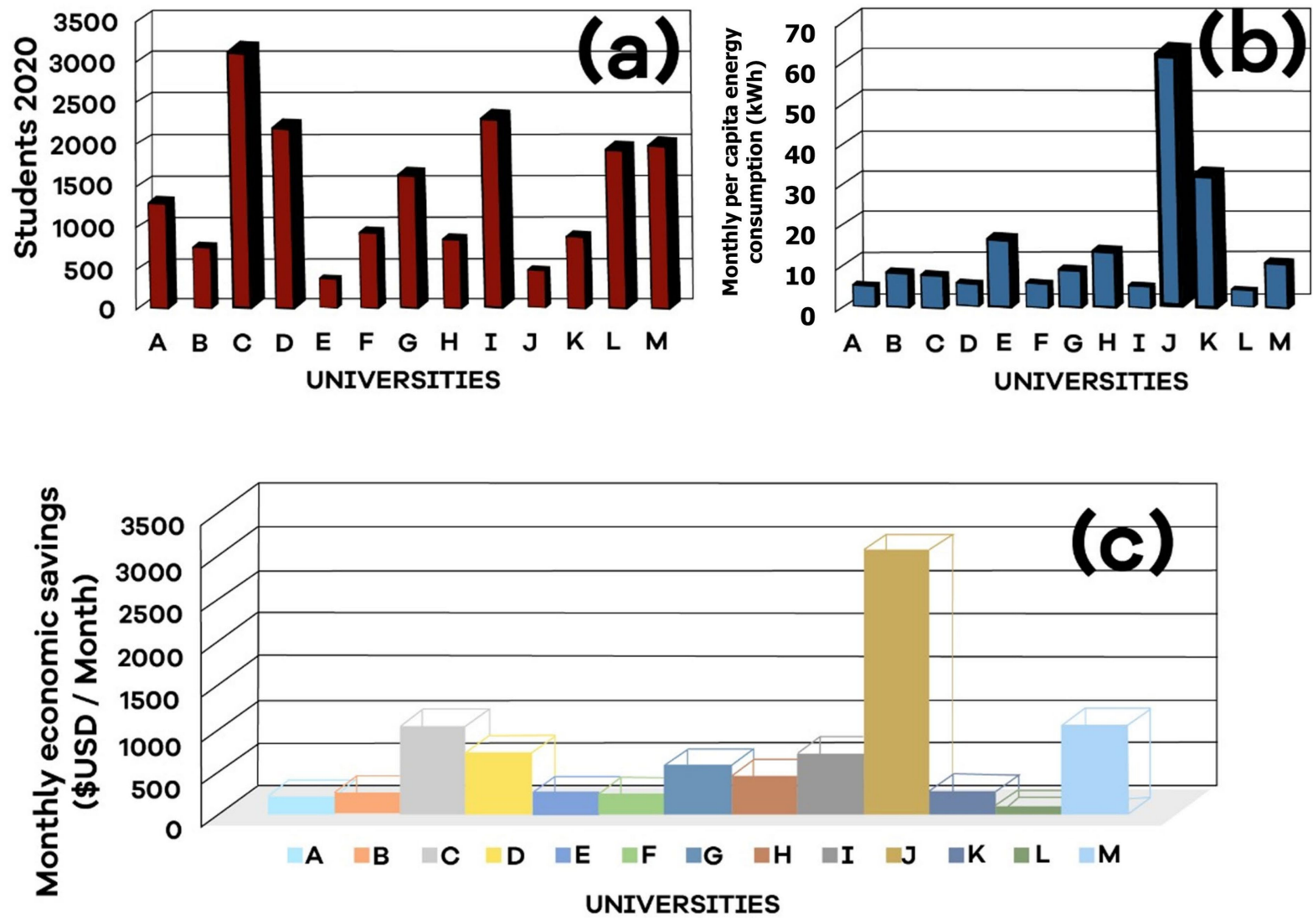

Figure 5. (a) Enrollment per university (b) Monthly electricity consumption per capita per student for each university (c) Monthly energy economic savings.

According to student enrollment for the 2019-2020 period, as well as the total energy consumption by university, Figure $5 \mathrm{~b}$ shows the monthly per capita energy consumption for students from each university, considering the average consumption prior to the pandemic. The diversity of this graph allows us to identify three different groups of average monthly per capita energy consumption: (a) Universities with high average monthly per capita consumption $>25 \mathrm{kWh}$ : whose high consumption may be due (J) to equipment and infrastructure available and $(\mathrm{K})$ to low enrollment and high infrastructure at this time for being a newly created institution. Institutions that are located at the extremes of the state of Michoacán, in the east and west of the state capital; (b) Universities with average consumption, monthly average per capita $<25 \mathrm{kWh}$ but $>8 \mathrm{kWh}$, where there are technological universities from the center and south of the state. In this category there are four universities; (c) Universities with a low average monthly per capita consumption $<8 \mathrm{kWh}$, which corresponds to the largest number of universities (seven), so that predominantly, study institutions maintain low consumption. Compared to universities in Europe, such as those in England, this electricity consumption of the three mentioned categories represents a low value [35,51]; on the other hand, it is within the levels of institutions such as the Universidad de Almería [25]. In Latin America, energy consumption in higher education institutions had a significant reduction and in an order of magnitude similar to the present study, as has been reported for countries such as Brazil [39]. 
As mentioned, the monthly per capita energy consumption levels were reduced within a few months of the start of the pandemic contingency plan, hence the per capita student consumption was also reduced. In some way, saving energy translates into lower costs associated with purchasing energy. In this context, according to the average rates for the unit consumption of each $\mathrm{kWh}$ in the universities that are around $0.125 \mathrm{USD} / \mathrm{kWh}$. With these data, the monthly economic savings were determined, which are shown in Figure $5 \mathrm{c}$. The total monthly financial savings is approximately \$ 8,882.25 USD. The lower the energy consumption, the greater the savings; these data are in accordance with Figure 2.

The data presented so far can be analyzed in an integrated way. According to reports from the Secretary of Energy of the Government of Mexico (SENER, for its acronym in Spanish) for 2020, the monthly electricity consumption per capita was $188.07 \mathrm{kWh}$. In this sense, the monthly electricity savings per university can be represented in a way equivalent to the number of people whose electricity needs could be satisfied (Figure 6). In parallel, Figure 6 shows the saving of electrical energy in terms of mitigating environmental impact (Ton $\mathrm{CO}_{2}$ ).

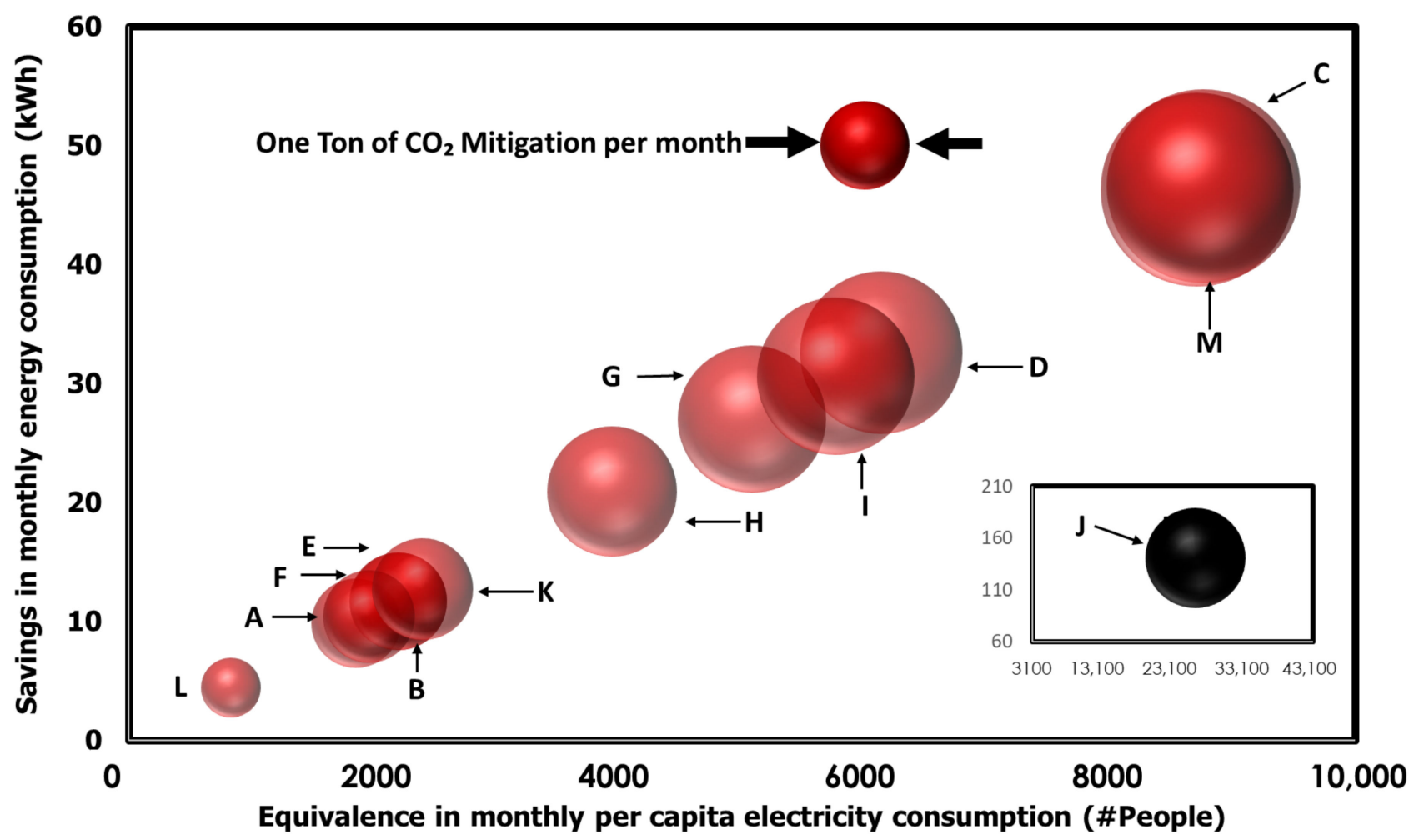

Figure 6. Multivariate analysis of energy consumption by university.

Figure 6 shows an increasing linear trend from " $\mathrm{L}$ " University to " $\mathrm{C}$ " University. It is worth highlighting the case of the " $\mathrm{J}$ " University, which is situated in a context of dimensions much higher than the average of the rest of the universities, due to its low enrollment and high consumption as it is newly created and has a natural growth scheme, which will be completed in a few more years. In the case of the other universities, the high enrollment has made it possible to reduce economic energy costs and reduce per capita consumption, as they are institutions with several generations of students.

The analysis of the electricity consumption data in the studied universities has made it possible to know the distribution of its magnitude over several months, before and during the first months of the SARS-CoV-2 pandemic, and also includes consumption data during the first peak of infections in 2020, when educational activities transitioned to a virtual scheme and universities closed their doors, operating minimally administrative processes (almost zero), mostly remotely and with sporadic visits to universities. All this 
represented a significant decrease and made it possible to identify decreasing curves from 2019 to 2020, as well as consumption plateaus with low magnitudes in 2020 compared to 2019. One of the interesting aspects, a priori to the analysis, was the distribution of electricity consumption that, suggestively, would represent a higher percentage for the operation of laboratory equipment and workshop machines. It should be noted that the studied universities contain spaces of this nature due to the approach of the higher level programs that are offered at these institutions. However, with the total closure- the most drastic due to the health contingency plan developed by the government of the state of Michoacán — carried out during the months of July to August, it was possible to identify in a general way that the savings in the electricity consumption of these universities did not exceed $50 \%$. Knowing that the equipment, machinery and comprehensive computer system were not operating, it is possible to understand that the base electrical energy consumption corresponding to the plateaus of 2020 (Figure 4) came mainly from the lighting and heating systems. The latter is associated with equipment that protects the general telecommunications system, as well as reagents and research material. However, in some cases, months ago, an emerging strategy was established for the suspension of research activities, which suggests a main consumption due to lighting.

\section{Discussion and Final Remarks}

Within the previous context, more than a year after the pandemic, it is necessary to reflect on the new educational normal of 2021 and the following years. This year, the state and national education system at the higher level is still virtually maintained, and although a possible return to face-to-face classes is expected in a staggered manner throughout 2021, the truth is that Mexico is still facing a scenario of new maximum spikes of contagion and deaths from the SARS-CoV-2 virus. So, there are some issues that should be specified, mainly because the new realities are closely linked to the electric power sector. In the first place, the immediate future will demand a system of hybrid lessons since, technologically, national education at the higher level accelerated its transition process towards virtual lesson schemes. Secondly, universities are now offering new virtual degrees, and this approach is expected to permeate all higher education institutions. The pandemic has generated enormous school dropouts, regardless of the fact that the educational system in Mexico is free. Furthermore, due to the economic impact of the pandemic, many university students have had to seek sources of employment to survive or supplement family income. The panorama will hardly ever be the same as the educational context prior to the pandemic. Thirdly, because many of the undergraduate programs may remain virtual due to the low number of students in the groups and facilities that the universities will provide to ensure the permanence and right to higher education of young Mexicans, the energy context will also change in these institutions.

Particularly in universities, it is possible to suggest sustainable energy alternatives to move towards self-managed, decentralized and resilient energy systems. If lighting represents one of the activities with a high consumption of electrical energy in these higher education institutions, photovoltaic systems could significantly satisfy this demand and generate local supply schemes to provide the necessary energy. To cite an example, by saving energy monthly during the pandemic months, for these case studies, the equivalent economic expense could be used in the acquisition of autonomous solar lighting systems that can currently be found at a low price of approximately 20 USD each, with lighting areas of $100 \mathrm{~m}^{2}$. Figure 7 shows the projection of the number of solar lights acquired with the monthly economic savings for each university. Monthly, the illuminated area would be equivalent to two soccer stadiums of those found in the capital of the state of Michoacán. In this sense, there may be multiple energy alternatives that allow optimizing the savings and efficiency of electrical energy in these universities [52]. 


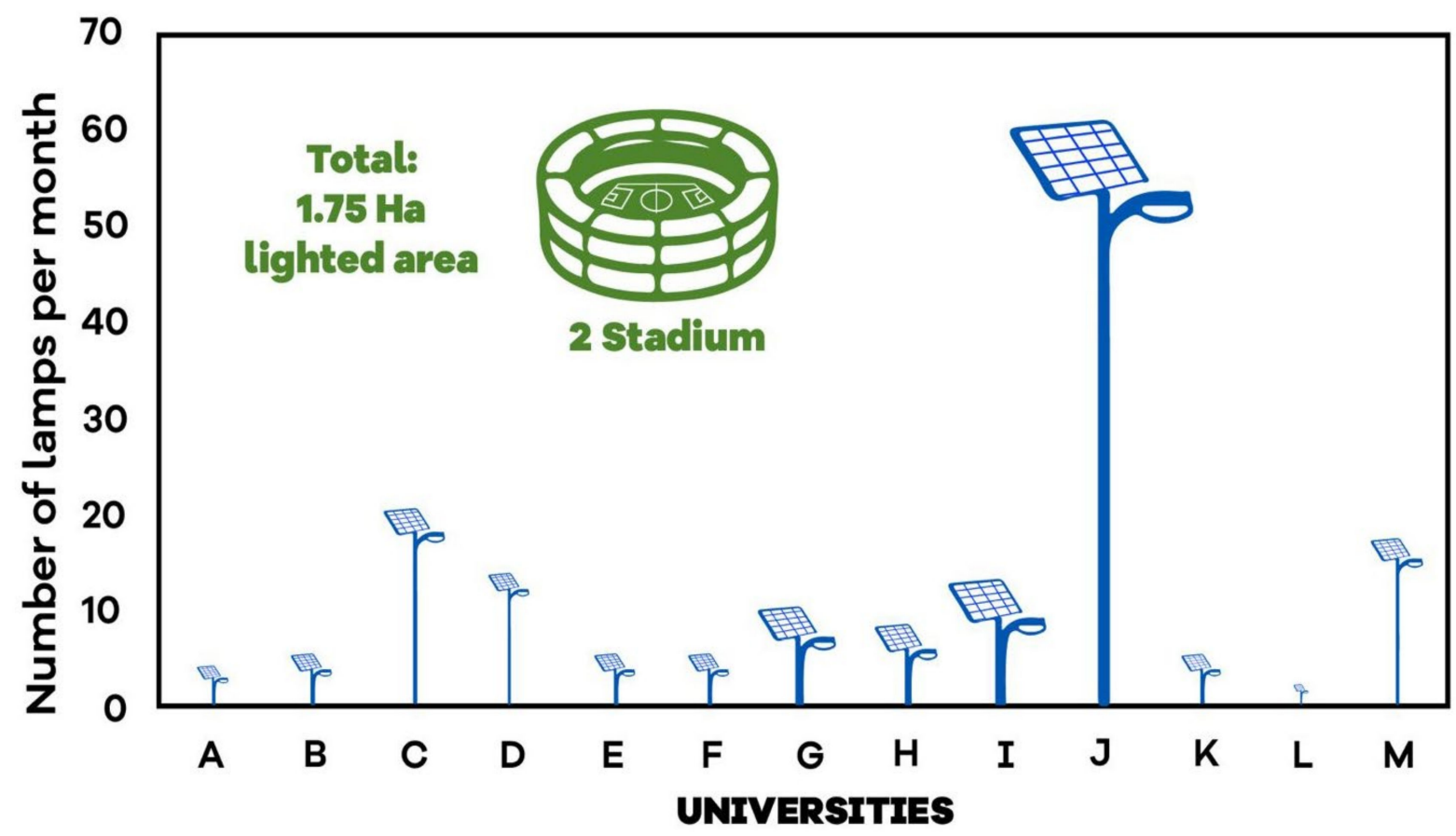

Figure 7. Projection of acquisition of solar systems for lighting.

In addition, the environmental and economic impact produced by the reduction in electricity consumption analyzed in this work, the closure of universities and virtual classes, has also collaterally decreased student mobility, which translates into economic savings and the mitigation of $\mathrm{CO}_{2}$ emissions by student and by university. To cite an example of the magnitude of student mobility, a comparative case for two university contexts is presented below; on one hand, a university located in an indigenous area, the "Universidad Intercultural Indígena de Michoacán", UIIM (A) and, on the other hand, an institution in the urban area of the capital of the state of Michoacán, the "Universidad Tecnológica de Morelia", UTM (M). This comparative scenario has been proposed to locate territorially diverse contexts, but also in conditions of different socioeconomic statuses among the students who attend both institutions (Figure 8).

In both cases, the transfers have points in common. In Mexico, the students do not live on the university campus; most of the students coming from places distant from where the universities are located rent rooms where they stay. The more distant the room, the smaller the rental cost. In this proposed scenario, a minimum transfer proximity radius of $10 \mathrm{~km}$ that most of the students travel to reach these two universities is considered, which are located in an industrial zone in the case of the UTM and an area of agricultural crops, in the case of UIIM - both distant from highly populated areas. The vehicles they mainly use are Urvan-type models with an average capacity of 15 passengers, whose transportation costs are around 0.5 USD per trip. They are internal combustion vehicles that consume gasoline and whose emission factor for this fuel is $2.3 \mathrm{KgCO}_{2} / \mathrm{L}$. Considering that mobility is total in each university under the previous approaches, Figure $8 \mathrm{~b}$ shows the analysis of monthly transportation costs for the enrollment of UTM (M) and UIIM (A) students; on the other hand, Figure $8 \mathrm{c}$ shows the comparative analysis of the energy consumption and emissions generation of both universities. As can be seen, this scenario shows the mitigation in energy consumption, emissions and expenses associated with mobility, under assumptions of minimal considerations, although clearly the real context is even more demanding in the analyzed variables. However, this proposed scenario allows us to partially know the magnitude of savings in terms of student mobility that, if extrapolated to all the analyzed universities, allows us to suggest a state panorama of the reduction of student mobility, as observed in Figure 9. 

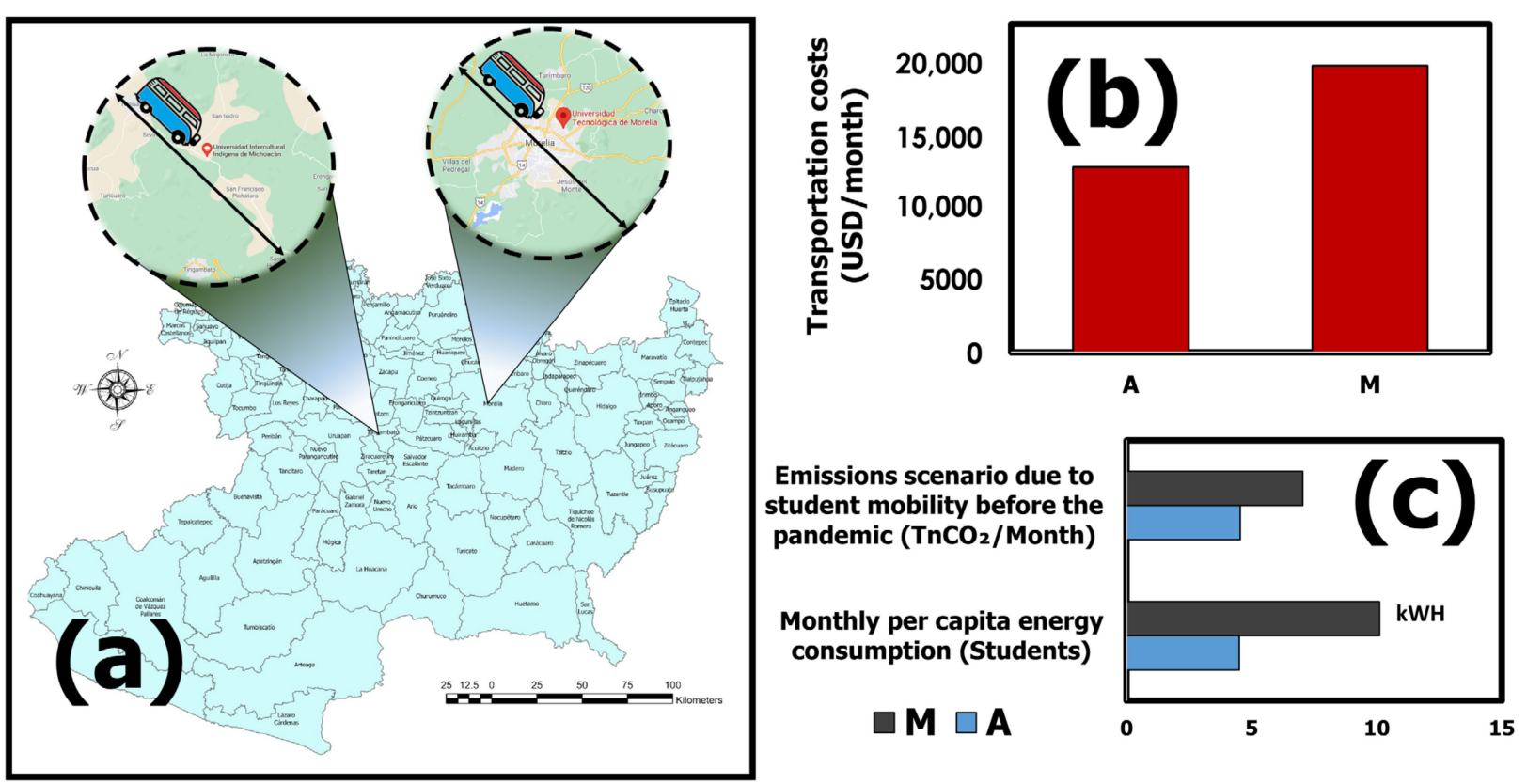

Figure 8. Student mobility reduction scenario: (a) Geographical location of 2 analysis cases $i=$ UTM, ii = UIIM (b) Monthly transportation costs for UTM and UIIM student enrollment (c) Comparative analysis of energy consumption and emissions generation UTM and UIIM.

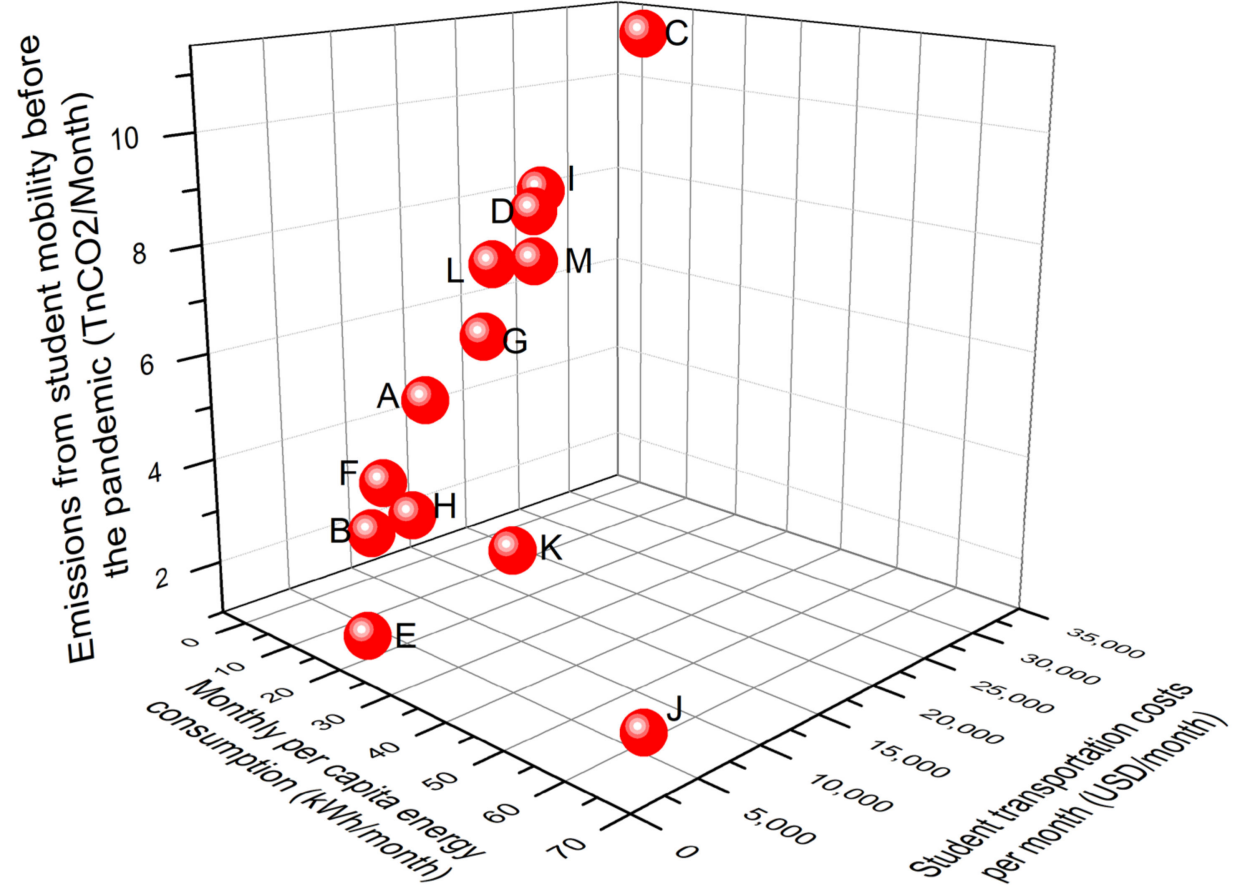

Figure 9. Extrapolated matrix of mobility impacts in 13 universities in Michoacán.

The present analysis is consistent with international experiences suggesting that the energy use is related to the attention to the pandemic. For example, it was observed that, based on sanitary restrictions in Brazil, there was less electricity consumption related to mobility, about $-20 \%$ and $-18 \%$ of electricity consumption [53]. Other studies have highlighted that, from the restrictive actions of the pandemic, energy consumption was affected mainly in areas where networks are shared, which, when the service is interrupted due to the absence or inefficiency of action plans, have seriously impacted the life of communities [54]. In addition, it has been observed that, although there is an economic 
recovery, it will not necessarily lead to better energy consumption. Everything will depend on the actions and post-pandemic policies that are promoted by the government, such as in the case of China, which expects a speedy economic recovery but recognizes that this will not necessarily involve an increase in energy consumption [55]. It has also been recognized that an improvement in air quality and a reduction in atmospheric pollutants has been perceived. Although the pandemic affects the economic aspect, it has been seen as a break from anthropogenic impacts for the environment and this has motivated a rethink of the need for energy transition and decarbonization [56]. This is key in educational matters, because important actions are being developed from the academy to promote energy decarbonization and sustainable energy consumption.

It should be noted that various studies suggest that energy consumption has varied during the pandemic and will not be the same after the pandemic, particularly because technology and planning strategies have been key to the new normal $[57,58]$, such as energy management strategies implementing renewable, profitable and efficient sources made in Ukraine [59]. It is also important to bear in mind that the effects on energy demand and carbon emissions depend on the socioeconomic conditions of each region or country, because factors like income, type of employment, nature of employment, urbanization, public services, and so forth, must be taken into account.

In the aforementioned context lies the importance of this study, which in a particular way allows us to know the dimension of savings in terms of the electricity consumption of public universities in the state of Michoacán, Mexico; as well as some energy consumption patterns in these institutions for lighting, laboratory machinery and equipment, and administrative computing systems. Knowing the priority consumptions helps us to define energy and technological transition strategies towards those that are renewable and that operate in a sustainable way, respectively. It also allows us to suggest particular strategies such as those shown in Figure 7. On the other hand, this research will serve to contribute to the diagnosis of energy consumption in the higher education sector, which is linked to three current energy management actions:

(a) The state development plan (Michoacán) with regard to energy management, which began to be elaborated in November 2021, as well as the institutional development plans that are generated in the different analyzed educational entities, whose plans are aligned because they have simultaneous validity, which may propose significant changes in terms of local energy transition and the use of efficient energy technologies where necessary.

(b) The current energy reforms in the country, which will be evaluated in the Mexican Congress in 2021, and the possibility that, in the following years, new reforms will be developed. It should be noted that in Mexico (2021), the national electricity system consists of the CFE as a state productive company, private investors, and small generators under the figure of distributed generation and clean distributed generation. The latter component promotes the possibility of electricity generation from the educational sector. Therefore, this research may contribute to the consumption patterns, the construction of programs and public policies that encourage the energy transition under current regulations after the pandemic, as well as the articulation of the climate change programs of the Ministry of the Environment and Natural Resources (SEMARNAT), which are linked to the General Directorate of Higher University and Intercultural Education of the Government of Mexico (DGESUI in Spanish) and to which all public universities of the country are attached.

(c) The generation of a decentralized system for the national educational system. This allows the generation of self-supply energy strategies and the promotion of carbon footprint reduction programs through student communities.

Finally, it is necessary to mention that it is possible that the saving of electricity in the universities will be transferred to the homes of each student (and the increase in consumption is not necessarily linear), increasing consumption the residential level as has been reported in some investigations (up to $30 \%$ increase) $[60,61]$, but it is clear that 
the null use of workshops and laboratories minimizes this transfer. However, unlike the consumption of electrical energy, mobility was reduced without transfer or equivalence [62]. The program of virtual classes and confinement due to the pandemic generated new patterns of energy consumption, these are some of the effects of the COVID-19 pandemic on the energy consumption of state universities in Michoacán, Mexico. The results shown in this research aim to propose a trend scenario towards lower consumption; once long distance education is maintained or in hybrid mode [63], energy consumption schemes must change and move towards resilient, affordable and sustainable models [64].

\section{Conclusions}

This case study allowed the evaluation of electricity consumption before and during the first year of the COVID-19 pandemic in 13 public state universities in the state of Michoacán in Mexico. The results have shown that the savings in energy consumption ranged between $10 \%$ and $90 \%$, and are still maintained since the universities have not returned to face-to-face classes as of August 2021. The economic savings exceed 8000 dollars per month for all universities and the total average monthly saving exceeds $70 \mathrm{MWh}$ of electrical energy, which translates into a reduction in emissions of nearly 500 tons per year of $\mathrm{CO}_{2 \mathrm{e}}$ (Total). In addition, a reduction in student mobility has also been identified, allowing an estimation of mitigation due to mobility reduction of more than 5 tons $\mathrm{CO}_{2}$ per month per university. In the studied institutions, the economic-environmental impacts during the pandemic are significant, and there may be renewable energy use strategies based on the economic savings during this health emergency, which, if integrated into an energy management and energy efficiency program could reduce consumption and promote selfgeneration of university electricity. This, in turn, could be linked to strategies to raise awareness of the carbon footprint of the university community, which can be linked to the results reported in this study. In an incipient way, new models of electricity consumption can be formulated that should exist with the new normality and contemporary remote education schemes. This research encourages the higher education system in Mexico to suggest strategies for energy self-sufficiency and sustainable mobility, which in sum can maintain low emissions, minimal economic expenses and reduction in the consumption of conventional energy sources in the student population.

This research also produces two contributions: (a) at the local level: making it possible to contribute to the state plan and university institutional development plans in energy matters, as well as to encourage the dimension of private consumption in higher education institutions with a perspective of supporting the current national energy reforms, and to the generation of an alternative proposal for a decentralized energy system for the national education system; and (b) on a global scale: it shows the effects on energy demand and carbon emissions that depend on the socio-economic conditions of each region or country. In educational matters this is key because the academy develops important actions to promote energy decarbonization and sustainable energy consumption. Therefore, knowing the dimension of consumption in the case of Mexico will encourage the systematization of diagnoses of this nature in Central and South America, and it is expected to be useful in the construction of public policies and post-pandemic reactivation programs that consider the transition towards renewable energy sources and sustainable technologies at the University level. This normality poses challenges from an energy perspective for the higher education sector that can be addressed with diagnoses before, during and after the pandemic, which are built with research like this, that, with the appropriate management measures, can encourage the construction of fair, affordable and sustainable energy scenarios.

Author Contributions: Conceptualization, L.B.L.-S. and C.A.G.; Data curation, J.J.A.-F., G.M.R.-T., M.M.-M., J.C.C.-H., T.d.N.J.M.-A., J.V.A.-V., M.d.C.R.-M., M.L.Á.-R., J.G.R.-Q., L.B.L.-S., M.d.C.F.-A. and C.A.G.; Formal analysis, L.B.L.-S., J.C.C.-H., G.M.R.-T., M.M.-M., J.V.A.-V. and M.L.Á.-R.; Funding acquisition, L.B.L.-S., M.M.-M., J.G.R.-Q. and C.A.G.; Investigation, L.B.L.-S., T.d.N.J.M.A., A.A.-M., G.M.R-T., M.M.-M. and M.d.C.R.-M.; Methodology, L.B.L.-S., J.C.C.-H. and C.A.G.; Project administration, J.J.A.-F., T.d.N.J.M.-A., J.C.C.-H., G.M.R.-T., M.d.C.R.-M., J.V.A.-V., M.L.Á.-R., 
J.G.R.-Q., N.E.R.-O. and C.A.G.; Resources, J.J.A.-F., T.d.N.J.M.-A., J.C.C.-H., M.M.-M., M.d.C.R.-M., J.V.A.-V., M.L.Á.-R. and N.E.R.-O.; Software, L.B.L.-S., J.C.C.-H. and C.A.G.; Supervision, G.M.R-T., M.d.C.R.-M., J.V.A.-V. and J.G.R.-Q.; Validation, L.B.L.-S., M.L.Á.-R., N.E.R.-O. and M.d.C.F.-A.; Visualization, A.A.-M., M.M.-M., M.L.Á.-R., J.G.R.-Q., N.E.R.-O. and M.d.C.F.-A.; Writing-Original draft, L.B.L.-S., A.A.-M. and M.d.C.F.-A.; Writing-review \& editing, L.B.L.-S., J.J.A.-F., A.A.-M. and M.d.C.F.-A. All authors have read and agreed to the published version of the manuscript.

Funding: This research received no external funding.

Institutional Review Board Statement: Not applicable.

Informed Consent Statement: Not applicable.

Data Availability Statement: Not applicable.

Acknowledgments: The authors thank the Sub-secretariat of Higher Education in the state of Michoacán, for the support in obtaining the analysis data, the Government of the State of Michoacán, the state Universities and the UNAM-DGAPA Postdoctoral Scholarship Program.

Conflicts of Interest: The authors declare no conflict of interest.

\section{References}

1. Zheng, J. SARS-CoV-2: An Emerging Coronavirus That Causes a Global Threat. Int. J. Biol. Sci. 2020, 16, 1678-1685. [CrossRef]

2. Law, P.K. COVID-19 Pandemic: Its Origin, Implications and Treatments. Open J. Regen. Med. 2020, 9, 43-64. [CrossRef]

3. Baldwin, R.; Weder, B. Economics in the Time of COVID-19; CEPR Press: London, UK, 2020; ISBN 9781912179282.

4. Bagchi, B.; Chatterjee, S.; Ghosh, R.; Dandapat, D. Bhaskar Bagchi Susmita Chatterjee Raktim Ghosh Dhrubaranjan Dandapat; Singapore Springer: Singapore, 2020; ISBN 9789811577819.

5. Zhu, X.; Liu, J. Education in and After Covid-19: Immediate Responses and Long-Term Visions. Postdigit. Sci. Educ. 2020, 2, 695-699. [CrossRef]

6. Benita, F.; Gasca-Sanchez, F. The Main Factors Influencing COVID-19 Spread and Deaths in Mexico: A Comparison between Phases I and II. Appl. Geogr. 2021, 134, 102523. [CrossRef]

7. Fernández-Rojas, M.A.; Esparza, M.A.L.; Campos-Romero, A.; Calva-Espinosa, D.Y.; Moreno-Camacho, J.L.; Langle-Martínez, A.P.; García-Gil, A.; Solís-González, C.J.; Canizalez-Román, A.; León-Sicairos, N.; et al. Epidemiology of COVID-19 in Mexico: Symptomatic pro Fi Les and Presymptomatic People. Int. J. Infect. Dis. 2021, 104, 572-579. [CrossRef] [PubMed]

8. Suárez, V.; Suarez Quezadab, M.; Oros Ruiz, S.; Ronquillo De Jesús, E. Epidemiología de COVID-19 En México: Del 27 de Febrero al 30 de Abril de 2020. Rev. Clín. Española 2020, 8, 463-471. [CrossRef] [PubMed]

9. Molina-Torres, R. A Comparative Analysis of Urban Development, Economic Level, and COVID-19 Cases in Mexico City. J. Urban Manag. 2021, 10, 265-274. [CrossRef]

10. Roel, P.; Sandoval, G. Resistir La Covid-19. Intersecciones En La Educación de Ciudad Juárez, México. Rev. Int. Educ. Justicia Soc. 2020, 9, 7-23.

11. Rashid, S.; Yadav, S. Impact of Covid-19 Pandemic on Higher Education and Research Impact of Covid-19 Pandemic on Higher Education and Research. Indian J. Hum. Dev. 2020, 14, 340-343. [CrossRef]

12. Surkhali, B.; Garbuja, K. Virtual Learning during COVID-19 Pandemic: Pros and Cons. J. Lumbini. Med. Coll. 2020, 8, 19-20.

13. Sun, L.; Tang, Y.; Zuo, W. Coronavirus Pushes Education Online. Nat. Mater. 2020, 19, 687. [CrossRef] [PubMed]

14. Shahzad, A.; Hassan, R.; Aremu, A.Y.; Hussain, A.; Lodhi, R.N. Effects of COVID-19 in E-Learning on Higher Education Institution Students: The Group Comparison between Male and Female. Qual. Quant. 2021, 55, 805-826. [CrossRef]

15. Erreyes-Toledo, N.M.; Álvarez-Lozano, M.I. Perspectives of Rural Education Students in Times of Pandemic. Cienciamatria 2021, VII, 46-65. [CrossRef]

16. Lloyd, M. Desigualdades educativas y la brecha digital en tiempos de COVID-19. In Educación y Pandemia: Una Visión Académica; Casanova Cardiel, E.H., Ed.; Centro Cultural Universitario, Instituto de Investigaciones sobre la Universidad y la Educación, Universidad Nacional Autónoma de México: Mexico City, Mexico, 2020; pp. 115-121.

17. Tadesse, S.; Muluye, W. The Impact of COVID-19 Pandemic on Education System in Developing Countries: A Review. Open J. Soc. Sci. 2020, 8, 159-170. [CrossRef]

18. Martínez, Y.M.; Alan, L.; Gamboa, A. Covid-19, Pobreza y Educación En Chiapas: Análisis a Los Programas Educativos Emergentes. Rev. Int. De Educ. Para La Justicia Soc. 2020, 9, 61-82. [CrossRef]

19. Sánchez-Cruz, E.; Masinire, A.; López, E.V. The Impact of COVID-19 on Education Provision to Indigenous People in Mexico. Rev. Adm. Pública 2021, 55, 151-164. [CrossRef]

20. Cohen, H. Challenges, Inequalities and COVID-19: Examples from Indigenous Oaxaca, Mexico. Glob. Public Health 2021, 16, 639-649. [CrossRef]

21. Rodriguez-Abitia, G. Coping with COVID-19 in Mexico: Actions for Educational Inclusion. Commun. Assoc. Inf. Syst. 2020, 48, 557-564. [CrossRef] 
22. Mendiola, M.S.; Ana, M.; Martínez, P.; Torres, R.; Servín, M.D.A.; Romo, A.K.H.; Mario, A.; Lara, B.; Rendón, V.J.; Jaimes, C.A. Retos Educativos Durante La Pandemia de COVID-19: Una Encuesta a Profesores de La UNAM. RDU 2020, $21,1-24$.

23. Ordorika, I. Pandemia y Educación Superior. Rev. Educ. Super. 2020, 49, 1-8.

24. Mokhtari, R.; Jahangir, M.H. The Effect of Occupant Distribution on Energy Consumption and COVID-19 Infection in Buildings: A Case Study of University Building. Build. Env. 2021, 190, 107561. [CrossRef]

25. Chihib, M.; Salmer, E.; Chourak, M.; Manzano-Agugliaro, F. Impact of the COVID-19 Pandemic on the Energy Use at the University of Almeria (Spain). Sustainability 2021, 13, 5843. [CrossRef]

26. Filimonau, V.; Archer, D.; Bellamy, L.; Smith, N.; Wintrip, R. Science of the Total Environment The Carbon Footprint of a UK University during the COVID-19 Lockdown. Sci. Total Environ. 2021, 756, 143964. [CrossRef]

27. IEA, US. Global Energy Review 2020: The Impacts of the Covid-19 Crisis on Global Energy Demand and CO2 Emissions; IEA: Paris, France, 2020.

28. Qarnain, S.S.; Sattanathan, M.; Sankaranarayanan, B.; Ali, S.M. Analyzing Energy Consumption Factors during Coronavirus (COVID-19) Pandemic Outbreak: A case study of residential society. Energy Sources Part A Recover. Util. Environ. Eff. 2020, 1-20. [CrossRef]

29. Chakraborty, I.; Maity, P. Science of the Total Environment COVID-19 Outbreak: Migration, Effects on Society, Global Environment and Prevention. Sci. Total Environ. 2020, 728, 138882. [CrossRef] [PubMed]

30. Alfaris, F.; Juaidi, A.; Manzano-Agugliaro, F. Improvement of Efficiency through an Energy Management Program as a Sustainable Practice in Schools. J. Clean. Prod. 2016, 135, 794-805. [CrossRef]

31. Samuels, J.A.; Grobbelaar, S.S.; Booysen, M.J. Energy for Sustainable Development Pandemic and Bills: The Impact of COVID-19 on Energy Usage of Schools in South Africa. Energy Sustain. Dev. 2021, 65, 101-106. [CrossRef] [PubMed]

32. Kang, H.; An, J.; Kim, H.; Ji, C.; Hong, T.; Lee, S. Changes in Energy Consumption According to Building Use Type under COVID-19 Pandemic in South Korea. Renew. Sustain. Energy Rev. 2021, 148, 111294. [CrossRef]

33. Abu-Rayash, A.; Dincer, I. Energy Research \& Social Science Analysis of the Electricity Demand Trends amidst the COVID-19 Coronavirus Pandemic. Energy Res. Soc. Sci. 2020, 68, 101682. [CrossRef]

34. Pang, Z.; Feng, F. Investigation of the Impacts of COVID-19 on the Electricity Consumption of a University Dormitory Using Weather Normalization. arXiv 2020, 1-10, preprint.

35. Birch, C.; Edwards, R.; Mander, S.; Sheppard, A. Electrical Consumption in the Higher Education Sector, during the COVID-19 Shutdown. In Proceedings of the 2020 IEEE PES/IAS Power Africa, Nairobi, Kenya, 25-28 August 2020; pp. 1-5. [CrossRef]

36. Helmers, E.; Chang, C.C.; Dauwels, J. Carbon Footprinting of Universities Worldwide: Part I-Objective Comparison by Standardized Metrics. Environ. Sci. Eur. 2021, 33, 1-25. [CrossRef]

37. Ernesto, D.; Franco, A. Carbon Footprint of Transport and Mobility: The Case of a Higher Education. Master's Thesis, School of Resource Wisdom, Jyväskylä University, Jyväskylä, Finland, March 2021.

38. Valls, K.; María, V. Carbon Footprint in Higher Education Institutions: A Literature Review and Prospects for Future Research Clean Technol. Env. Policy 2021, 23, 2523-2542. [CrossRef]

39. Lopes, D.A.; Giusti, G.; Rampasso, I.S.; Carlos, A.; Junior, F.; Anechini, M.; Marins, S.; Anholon, R. The Environmental Impacts of Face-to-Face and Remote University Classes during the COVID-19 Pandemic. Sustain. Prod. Consum. 2021, 27, 1975-1988. [CrossRef]

40. Clabeaux, R.; Carbajales-Dale, M.; Ladner, D.; Walker, T. Assessing the Carbon Footprint of a University Campus Using a Life Cycle Assessment Approach. J. Clean. Prod. 2020, 273, 122600. [CrossRef]

41. Tai, W.; He, L.; Zhang, X.; Pu, J.; Voronin, D. Characterization of the Receptor-Binding Domain (RBD) of 2019 Novel Coronavirus: Implication for Development of RBD Protein as a Viral Attachment Inhibitor and Vaccine. Cell. Mol. Immunol. 2020, 17, 613-620. [CrossRef]

42. Nú, C. Changes in Air Quality in Mexico City, London and Delhi in Response to Various Stages and Levels of Lockdowns and Easing of Restrictions During. Environ. Pollut. 2021, 285, 117664. [CrossRef]

43. Ivanko, D.; Ding, Y.; Nord, N. Analysis of Heat Use Profiles in Norwegian Educational Institutions in Conditions of COVIDLockdown. J. Build. Eng. 2021, 43, 102576. [CrossRef]

44. Smith, D.R. University Campuses Need People in Them. EMBO Rep. 2021, 22, e52591. [CrossRef] [PubMed]

45. Lahcen, B.; Vrancken, J.B.K.; Da, Y.D.C.; Paes, S. Green Recovery Policies for the COVID-19 Crisis: Modelling the Impact on the Economy and Greenhouse Gas Emissions. Environ. Resour. Econ. 2020, 76, 731-750. [CrossRef]

46. Iqbal, S.; Bilal, A.R.; Nurunnabi, M.; Iqbal, W.; Alfakhri, Y.; Iqbal, N. It Is Time to Control the Worst: Testing COVID-19 Outbreak, Energy Consumption and CO 2 Emission. Environ. Sci. Pollut. Res. 2021, 28, 19008-19020. [CrossRef]

47. Klenert, D.; Funke, F.; Mattauch, L.; Callaghan, B.O. Five Lessons from COVID-19 for Advancing Climate Change Mitigation. Environ. Resour. Econ. 2020, 76, 751-778. [CrossRef] [PubMed]

48. Brooks-Pollock, E.; Christensen, H.; Trickey, A.; Hemani, G.; Nixon, E.; Thomas, A.C.; Turner, K.; Finn, A.; Hickman, M.; Relton, C.; et al. Layered Interventions. Nat. Commun. 2021, 12, 1-10. [CrossRef]

49. México National Registry of Emissions of México, Factor de Emisión Del Sistema Eléctrico. 2020. Available online: https://www.gob.mx/cms/uploads/attachment/file/538473/Factor_emision_electrico_2019.pdf (accessed on 7 November 2021).

50. Le Quéré, C.; Jackson, R.B.; Jones, M.W.; Smith, A.J.P.; Abernethy, S.; Andrew, R.M.; De-Gol, A.J.; Willis, D.R.; Shan, Y.; Canadell, J.G.; et al. During the COVID-19 Forced Confinement. Nat. Clim. Chang. 2020, 10, 647-654. [CrossRef] 
51. Amber, K.P.; Aslam, M.W.; Id, A.M.; Kousar, A.; Younis, M.Y.; Akbar, B.; Chaudhary, G.Q.; Hussain, S.K. Energy Consumption Forecasting for University Sector Buildings. Energies 2017, 10, 1579. [CrossRef]

52. Ghenai, C.; Bettayeb, M. Data Analysis of the Electricity Generation Mix for Clean Energy Transition during COVID-19 Lockdowns. Energy Sources Part A Recovery Util. Environ. Eff. 2021, 1-21. [CrossRef]

53. Carvalho, M.; Bandeira, D.; Delgado, D.M. Effects of the COVID-19 Pandemic on the Brazilian Electricity Consumption Patterns. Int. J. Energy Res. 2021, 45, 3358-3364. [CrossRef]

54. Qarnain, S.S.; Muthuvel, S.; Bathrinath, S. Materials Today: Proceedings Review on Government Action Plans to Reduce Energy Consumption in Buildings amid COVID-19 Pandemic Outbreak. Mater. Today Proc. 2021, 45, 1264-1268. [CrossRef]

55. Wang, Q.; Zhang, F. What Does the China's Economic Recovery after COVID-19 Pandemic Mean for the Economic Growth and Energy Consumption of Other Countries? J. Clean. Prod. 2021, 295, 126265. [CrossRef]

56. Tuan, A.; Ni, S.; Olcer, A.I.; Chyuan, H.; Chen, W.; Tung, C.; Thomas, S.; Bandh, S.A.; Phuong, X. Impacts of COVID-19 Pandemic on the Global Energy System and the Shift Progress to Renewable Energy: Opportunities, Challenges, and Policy Implications. Energy Policy 2021, 154, 112322. [CrossRef]

57. Strielkowski, W.; Firsova, I.; Lukashenko, I. Effective Management of Energy Consumption during the COVID-19 Pandemic: The Role of ICT Solutions. Energies 2021, 14, 893. [CrossRef]

58. Gholamzadeh, A.; Ariani, F. Covid-19 Shock: Development of Strategic Management Framework for Global Energy. Renew. Sustain. Energy Rev. 2021, 139, 110643. [CrossRef]

59. Shcherbak, V.; Gryshchenko, I.; Nifatova, O.; Bobrovnyk, V.; Verhun, M. Energy-Innovation Knowledge Common Connection Point Management in Preventing Outbreak of the Covid-19 Pandemicin a University. Glob. J. Environ. Sci. Manag. 2022, 8, 45-58. [CrossRef]

60. Krarti, M.; Aldubyan, M. Review Analysis of COVID-19 Impact on Electricity Demand for Residential Buildings. Renew. Sustain. Energy Rev. 2021, 143, 110888. [CrossRef]

61. Jiang, P.; Fan, Y. Van Impacts of COVID-19 on Energy Demand and Consumption: Challenges, Lessons and Emerging Opportunities. Appl. Energy 2021, 285, 116441. [CrossRef] [PubMed]

62. Abu-Rayash, A.; Dincer, I. Energy Research \& Social Science Analysis of Mobility Trends during the COVID-19 Coronavirus Pandemic: Exploring the Impacts on Global Aviation and Travel in Selected Cities. Energy Res. Soc. Sci. 2020, 68, 101693. [CrossRef] [PubMed]

63. Azor, C. Beyond COVID-19 Supernova. Is Another Education Coming? Supernova. J. Prof. Cap. Community 2020, 5, 381-390. [CrossRef]

64. Klemeš, J.J.; Van Fan, Y.; Jiang, P. COVID-19 Pandemic Facilitating Energy Transition Opportunities. Int. J. Energy Res. 2020, 45, 1-7. [CrossRef] [PubMed] 